кандидат педагогічних наук, доцент, доцент кафедри дошкільної педагогіки і психології та спеціальної освіти імені проф. Т. І. Поніманської Рівненського державного гуманітарного університету, м. Рівне, Україна ORCID: 0000-0002-5406-1963

e-mail:nataliia.horohakha@rshu.edu.ua

\title{
ПІДГОТОВКА ТА ПРОВЕДЕННЯ НАВЧАЛЬНИХ ЕКСКУРСІЙ У ПРИРОДУ З МОЛОДШИМИ ШКОЛЯРАМИ, ЯКІ МАЮТЬ ПОРУШЕННЯ МОВЛЕННЯ
}

Анотація. У статті розглядається використання екскурсій у природу як форми вивчення природознавства 3 молодшими школярами, які мають порушення мовлення. Особлива увага зосереджується на значенні екскурсій у формуванні визначених Державним стандартом початкової освіти природничої та екологічної компетентностей молодшого школяра. Автор аналізує класифікацію екскурсій та їх структуру, виокремлює роль екскурсій у корекційній складовій вивчення природознавства у спеціальній початковій школі для дітей з тяжкими порушеннями мовлення, доводить, що ефективність екскурсії значною мірою залежить від того, наскільки вдало продумана вчителем іiі структура, як у ній передбачено розв'язання окремих дидактичних та корекційних цілей. Пропонується до структури екскурсії вводити підготовчу та післяекскурсійну роботу з учнями, а також пішохідний перехід від школи до місця екскурсії та у зворотному напрямку. Наведено приклади методичних приймів роботи вчителя на етапі підготовки молодших школярів з тяжкими порушеннями мовлення до екскурсії, під час пішохідного переходу та у післяекскурсійній роботі, рекомендації щодо організації спостережень. Також наголошено, що підготовка і проведення екскурсії з учнями спеціальної початкової школи для дітей з мовленнєвими порушеннями потребує від учителя врахування тих труднощів, які вони мають у навчанні взагалі та у пізнанні природного довкілля зокрема.

Ключові слова: екскурсія, молодші школярі, природознавство, порушення мовлення, підготовка екскурсії, спостереження, післяекскурсійна робота.

Постановка проблеми. Навчальна екскурсія - це одна 3 традиційних форм вивчення природознавства у початковій школі. Ї̈̈ значення та роль визначив ще у XVIII сторіччі французький філософ-просвітитель Ж. Ж. Руссо, обгрунтовуючи думку про те, що саме екскурсії та прогулянки в природу розвивають у дітей творчу спостережливість, допитливість та 


\section{Інноватика у вихованні. Випуск 14. 2021.}

самостійність у дослідженні оточуючого світу. Він пропонував використовувати екскурсії як основний шлях виховання та навчання дитини до 10-12 років.

Головна цінність екскурсії полягає у тому, що вона дозволяє наблизити учнів до природи, показати їм цілісність, єдність та багатогранність природного світу, наявність у ньому певних зв'язків та закономірностей, котрі на екскурсії простежуються чіткіше. Екскурсія $є$ також визнаним засобом підвищення інтересу молодших школярів до пізнання природи. Як зазначав В. Сухомлинський, під впливом спілкування 3 природою починає діяти могутній емоційний стимул розумової праці - подивування, яке породжує бажання знати; а ще під час цього шліфується важливий інструмент мислення - слово. Не випадково видатний педагог називав свої «уроки серед природи» «подорожами до джерел думки і слова, які нічим не можна замінити» (Сухомлинський, 1977). Саме наявність під час екскурсії додаткових можливостей для стимулювання мовленнєвого розвитку школярів робить цю форму вивчення природознавства такою важливою у спеціальній початковій школі чи інклюзивному класі, де навчаються учні 3 порушеннями мовлення.

Значення екскурсій особливо зростає у контексті реалізації принципів Нової української школи, яка передбачає вивчення природознавства у змісті інтегрованого курсу «Я досліджую світ». Адже саме під час безпосереднього пізнання природи на екскурсії вчитель має реальні можливості для залучення молодших школярів до спостережень та експериментів, двох найважливіших способів дослідження світу, оволодіння якими передбачено Державним стандартом початкової освіти (Державний стандарт початкової освіти, 2018).

У методичних рекомендаціях для вчителів наголошено, що на сучасному етапі реформування початкової школи необхідно, аби екскурсії перетворювалися на регулярні загальнопізнавальні та розвивальні заняття. Ця робота важлива не лише в урочний час, а й з групами продовженого дня, де екскурсії призначені також для активного відпочинку школярів після уроків (Гільберг та ін., 2019, с. 95). Водночас, аналіз практики дозволяє стверджувати, що можливості екскурсій не повною мірою використовуються вчителями, та й самих екскурсій планується недостатньо. Причин цьому є, очевидно, декілька, серед іншого й те, що проведення екскурсії потребує значної підготовчої роботи, сформованості у вчителя низки організаційних та методичних умінь, та, зрештою, наявності у найближчому природному оточенні місць, які можна не просто відвідати 3 учнями, а й організувати там повноцінну навчальнопізнавальну діяльність школярів.

Аналіз останніх досліджень 3 проблеми. Питання проведення навчальних екскурсій з молодшими школярами неодноразово ставали предметом наукових досліджень та методичних розробок для вчителів. Зокрема, Т. Байбара на основі узагальнення низки наукових досліджень та 


\section{Інноватика у вихованні. Випуск 14. 2021.}

практики початкової освіти детально обгрунтовує методику проведення екскурсії як одного з типів уроків природознавства у початковій школі (Байбара, 1998). На ii думку, класифікація уроків-екскурсій має здійснюватися за двома ознаками: обсягом власне предметного змісту теми екскурсії (виділяється однотемна та багатотемна екскурсії) та його місцем у структурі вивчення розділу або курсу (вступна, поточна, підсумкова). Зауважимо, що нам такий підхід до класифікації екскурсій видається дещо неповним, оскільки він не враховує, до прикладу, дидактичної мети екскурсії, своєрідності можливих місць проведення, інтегрованого змісту курсу «Я досліджую світ». У інших авторів ми знаходимо уже більш розгалужені класифікації екскурсій. До прикладу, Т. Васютіна до двох вказаних критеріїв пропонує ще враховувати взаємозв'язок змісту екскурсії та навчальної програми, що дозволяє їй виділяти програмні та позапрограмні екскурсії (Васютіна, 2017). Найповніше класифікують екскурсії Т. Гільберг та С. Тарнавська, які вважають доцільним класифікувати екскурсії з навчального курсу «Я досліджую світ» за такими критеріями:

зміст (тематичні, комплексні);

об'єкти вивчення (природничо-наукові, соціальні, виробничі, здоров'язбережувальні, екологічні та історичні);

дидактична мета (вступні, поточні, узагальнюючі) (Гільберг та Тарнавська, 2019).

Сучасними науковцями детально обгрунтовані загальні педагогічні умови проведення екскурсій в природу, визначена структура уроківекскурсій різних видів. Загалом дослідники відзначають, що основні відмінності екскурсії від уроку, який проводиться у класі, пов'язані з тим, що на екскурсії пізнавальна діяльність відбувається у складніших умовах, на фоні піднесеного емоційного стану учнів, спричиненого зміною звичних умов навчання, різноманітних відволікаючих факторів, що екскурсія не обмежена жорстко в часі тощо. Ї̈̈ результативність значною мірою залежить від психологічної установки, яку педагог повинен створити в учнів перед екскурсією. Тому проведення екскурсії передбачає обов'язковий етап підготовчої роботи. Також вчені наголошують на необхідності проведення так званої післяекскурсійної роботи, метою якої $\epsilon$ узагальнення отриманих знань, застосування їх у роботі з зібраним на екскурсії природним матеріалом тощо. Однак в більшості джерел, визначаючи структуру екскурсії, автори не включають до неї ні підготовчої, ні післяекскурсійної роботи (Байбара, 1998; Васютіна, 1917; Гільберг та Тарнавська, 2019), обгрунтовуючи їх лише як етапи роботи вчителя. Незначна увага вчених приділяється і такому важливому моменту екскурсії, як пішохідний перехід від школи до місця проведення екскурсії, який теж, безперечно, має певні дидактичні можливості.

Проаналізовані вище дослідження розглядають методику проведення екскурсій у загальноосвітній початковій школі, однак визначені авторами прийоми організації пізнавальної діяльності учнів у природі важливі і для 


\section{Інноватика у вихованні. Випуск 14. 2021.}

вчителів, які працюють 3 дітьми, що мають особливі освітні потреби, обумовлені, зокрема, проблемами мовленнєвого розвитку. Підготовка i проведення екскурсії з учнями спеціальної початкової школи для дітей 3 мовленнєвими порушеннями потребує від учителя врахування тих труднощів, які вони мають у навчанні взагалі та у пізнанні природного довкілля зокрема. Як зазначає В. Тарасун, існує принаймні п'ять типів таких утруднень, що пов'язані як з репродуктивним, так і з творчим застосуванням знань, плануванням власної пізнавальної діяльності, самостійним пошуком нових знань та оцінкою правильності виконаного пізнавального завдання. Причинами труднощів є властиві школярам 3 порушеннями мовлення уповільненість процесів пригадування, недорозвиток репродуктивних процесів, недоліки в систематизації знань, невміння відтворити спосіб виконання завдання, невміння встановлювати причинно-наслідкові зв'язки і залежності в явищах та предметах тощо (Тарасун, 2011). Ю. Рібцун наголошує, що школярі з розладами мовлення часто не проявляють особливого інтересу до навчальної діяльності, їх також характеризують ослабленість мотиваційної основи діяльності, недостатність прояву вольових зусиль, деяка фрагментарність у сприйманні зорової та вербальної інформації, труднощі у сприйманні та розумінні зверненого мовлення тощо (Рібцун, 2020). Очевидно, що подолання цих проблем чи, принаймні, їх пом'якшення, вимагає застосування спеціальних прийомів корекції пізнавальної діяльності учнів та підвищення їхнього пізнавального інтересу до природи і пізнавальної активності на всіх етапах екскурсії.

Оскільки корекція цих труднощів пов'язана із загальним розумовим розвитком учнів, формуванням основних прийомів інтелектуальної діяльності (порівняння, співставлення, аналізу, синтезу, узагальнення тощо), варто зважати на думку фахівців щодо проведення навчальної роботи, зокрема, екскурсій 3 молодшими школярами, які мають інтелектуальні порушення. Зокрема, вказуючи на те, що загалом екскурсія значно допомагає не тільки в правильному формуванні уявлень про природу, а й максимально сприяє корекції недоліків інтелектуального розвитку учнів, дослідники В. Шибецька та Н. Кравець попереджають, що зміна умов проведення заняття може й негативно позначитися на увазі, якості сприйнятого матеріалу, поведінці окремих учнів - легко збудливих, схильних до швидкої перевтоми. У зв'язку з цим особливого значення набуває підготовка учнів до екскурсії (Шибецька та Кравець, 2015).

Мета статті - розкрити особливості підготовки та проведення навчальних екскурсій природознавчого змісту в спеціальній початковій школі для дітей з тяжкими порушеннями мовлення.

Виклад основного матеріалу дослідження. Державний стандарт початкової освіти, відповідно до якого працює НУШ, передбачає формування у молодших школярів низки ключових компетенцій, безпосередньо пов'язаних із реалізацією змісту природничої освітньої галузі. А саме, таких, як компетентності у галузі природничих наук, 


\section{Інноватика у вихованні. Випуск 14. 2021.}

техніки i технологій, що передбачають формування допитливості, прагнення шукати і пропонувати нові ідеї, самостійно чи в групі спостерігати та досліджувати, формулювати припущення і робити висновки на основі проведених дослідів, пізнавати себе і навколишній світ шляхом спостереження та дослідження, а також екологічної компетентності, що передбачає усвідомлення основ екологічного природокористування, дотримання правил природоохоронної поведінки, ощадного використання природних ресурсів (Державний стандарт початкової освіти, 2018). Тому навчальну екскурсію необхідно розглядати перш за все як засіб компетентнісного розвитку молодших школярів 3 тяжкими порушеннями мовлення, форму навчальної роботи, яка дозволяє учневі не лише безпосередньо пізнавати світ, а й набувати вмінь робити це за допомогою самостійним спостереженням та дослідженням, накопиченням досвіду раціонального природокористування та природоохоронної діяльності.

Ефективність екскурсії залежить від того, наскільки точно продумана вчителем іï структура, як у ній передбачено розв'язання окремих дидактичних та корекційних цілей. Як ми уже зазначали, важливо у структурі екскурсії передбачити та пов'язати між собою всі етапи організації пізнавальної діяльності школярів. Тому пропонуємо таку загальну структуру навчальної екскурсії:

1. Підготовчий етап - спрямований на те, щоб організувати учнів, виявити їх досвід, налаштувати на майбутнє пізнання природи, спонукати до цікавості. Цю роботу варто розпочинати за декілька днів до екскурсії. Потреба спеціальної підготовки школярів з мовленнєвими порушеннями до екскурсії обумовлена тим, що педагогові треба створити загальну емоційну атмосферу, налаштувати їх на майбутнє спілкування з природою. У роботі з учнями $з$ ТПМ ефективними будуть такі прийоми створення емоційного настрою перед екскурсією, як повідомлення нових, невідомих відомостей про ті предмети та явища, 3 якими передбачається ознайомитися на екскурсії, оскільки інформація, яка до деякої міри протирічить знанням, які вже мають учні, збуджує їх пізнавальний інтерес та активність; використання творів мистецтва (картин, музики, віршів), народознавчого матеріалу (загадок, прислів”їв, легенд, прикмет), що впливають на емоційні компоненти пізнавального інтересу; постановка проблемно-ігрового завдання чи створення проблемної ситуації; попередня підготовка дітьми екскурсійного обладнання тощо.

Крім того, слід актуалізувати знання та уміння, необхідні для виконання навчальних завдань на екскурсії. Для цього найчастіше використовують бесіди та розглядання дидактичних картин. У роботі 3 учнями, що мають мовленнєві проблеми, доцільно поєднати бесіду 3 короткотривалим спостереженням за одним із об'єктів, подібних до того, що передбачений у зміст, екскурсії (наприклад, перед екскурсією до водойми - за рибкою в акваріумі). Закінчується підготовчий етап 


\section{Інноватика у вихованні. Випуск 14. 2021.}

безпосередньо перед початком екскурсії постановкою іï мети i нагадуванням правил поведінки під час пішохідного переходу та у природі.

2. Пішохідний перехід до місця екскурсії використовується для уточнення, узагальнення знань учнів, проведення спостережень за довкіллям. Основними прийомами роботи вчителя на цьому етапі $\epsilon$ коментар та короткі пояснення. Коментарі педагога допомагають зосереджувати увагу учнів на тих об’єктах довкілля, які цікаві для спостереження, полегшують сприймання та аналіз, а пояснення допомагають встановлювати взаємозв'язки та залежності в навколишньому світі.

3. Основний етап (власне екскурсія) - організація пізнавальної та практичної діяльності школярів. Традиційно основний етап екскурсії поєднує колективні та самостійні спостереження за природою або за працею дорослих, бесіди з дорослими, за працею яких спостерігають учні, дидактичні та рухливі ігри, виконання практичних і дослідницьких завдань. Особливо важливо правильно організувати початок спостереження, щоб забезпечити цілісне сприйняття об'єкта, показати його естетичні властивості. У структуру спостереження слід вводити такі прийоми, як виконання нескладних самостійних завдань (серед них повинні переважати проблемно-пошукові, дослідницькі), пояснення та евристична бесіда, екологічний тренінг, ігрові прийоми та трудові доручення. Під час проведення екскурсії важливо правильно розмістити учнів, аби дати можливість розглянути об'єкт спостереження з різної відстані. Доцільно вдаватися не лише до фронтальної, а й до індивідуальногрупової та колективно-групової організації пізнання, чергувати колективні та самостійні спостереження, ігри та практичні завдання. Практична діяльність на екскурсії залежить від ії змісту: на екскурсіях у природу учні збирають природний матеріал, залучаються до природоохоронної діяльності (садять саджанці дерев, очищають джерело тощо); на екскурсіях до сільськогосподарських об'єктів допомагають дорослим у зборі врожаю, інших видах сільськогосподарської праці; на екологічних екскурсіях здійснюють екологічний моніторинг, беруть проби води чи грунту для вивчення тощо.

4. Пішохідний перехід від місця екскурсії до школи, тобто зворотній шлях варто використати для обміну враженнями учнів від екскурсії. Це має бути у формі невимушеної розмови учнів між собою, а роль педагога полягає зводиться до того, щоб перед початком руху нагадати правила культури поведінки (розмовляти з тим, хто йде біля тебе, так, щоб ваша розмова не заважала іншим тощо), націлити на зміст розмови (розкажіть один одному, що вас найбільше зацікавило, здивувало, вразило, викликало позитивні чи негативні емоції тощо). Така рефлексія важлива як з точки зору загального розумового розвитку молодших школярів, так і як метод корекційної роботи з учнями з мовленнєвими порушеннями. Оскільки саме у такому обміні враженнями відбувається перший етап систематизації отриманих знань, а також учні мають можливість сформулювати, а отже й усвідомити емоційно-ціннісне ставлення до природи, що виникло під час екскурсії. 


\section{Інноватика у вихованні. Випуск 14. 2021.}

5. Післяекскурсійна робота - спрямовується на узагальнення i застосування знань, отриманих під час основного етапу екскурсії. Проводити післяекскурсійну роботу слід не одразу після повернення, адже для того, щоб емоційні враження від побаченого вляглися, потрібен деякий час. Але й відкладати надовго не варто, знаючи про особливості пізнавальної діяльності молодших школярів з ТПМ. Оптимальним часом для післяекскурсійної роботи $\epsilon$ наступні день-два за екскурсією. Ефективними у роботі 3 учнями 3 ТПМ будуть такі прийоми післяекскурсійної роботи, як відображення вражень від екскурсії у малюнках, аплікаціях; робота із зібраним природним матеріалом (проведення елементарних дослідів, порівняльних розглядань або підготовка гербаріїв та колекцій); спостереження за живими об'єктами, що тимчасово розміщуються у класному кутку природи після екскурсії (інсектацій для комах можна розмістити у класі не більше, ніж на тиждень, такий самий час можна тримати в окремому акваріумі мальків риб місцевих водойм, до місяця можуть жити у терарії земноводні та плазуни тощо). Хоча принагідно маємо зауважити, що варто особливо дбати про те, аби діти усвідомлювали, що всіх живих істот можна приносити в клас ненадовго, щоб поспостерігати за ними і обов'язково слід повернути у природне середовище.

Висновки і перспективи подальших розвідок. Отже, навчальна екскурсія за умови продуманої структури, підібраних педагогом 3 урахуванням особливостей пізнавальної діяльності учнів методичних прийомів, $\epsilon$ ефективним засобом формування природничої та екологічної компетенції молодших школярів 3 порушеннями мовлення, важливим елементом корекційної роботи, спрямованої на формування їх пізнавальних інтересів та навчальних умінь. Отримані на екскурсіях враження також можуть скласти підгрунтя до роботи логопеда 3 учнями 3 розвитку їхнього мовлення, розширення словника, формування зв'язних висловлювань, подолання інших порушень. Перспективи подальших розвідок вбачаємо в уточненні класифікації екскурсій та визначенні особливостей методики проведення екскурсій різних видів залежно від місць їх проведення (екскурсій власне у природу та до сільськогосподарських об'єктів, музеїв та місць, створених людиною для збереження та вивчення природи тощо).

\section{СПИСОК ВИКОРИСТАНИХ ДЖЕРЕЛ}

Сухомлинський, В. (1977). Вибрані твори в 5 m. T. 3: Серце віддаю дітям; Народження громадянина; Листи до сина. Київ: «Радянська школа», 668 с.

Державний стандарт початкової освіти (2018). URL: https://www.kmu.gov.ua/storage/app/uploads/public/5a8/de2/5e1/5a8de25e1504c87758 3228.doc [Дата звернення 28.08.2021]

Гільберг,Т., Тарнавська, С. та Павич, Н (2019). Нова українська школа: методика навчання інтегрованого курсу «Я досліджую світ» у 1-2 класах закладів середньої освіти на засадах компетентнісного підходу. Київ: «Генеза», 256 с.

Байбара, Т. (1998). Методика навчання природознавства в початкових класах. Київ: Веселка, 338 с. 


\section{Інноватика у вихованні. Випуск 14. 2021.}

Васютіна, Т. (2017) Методичні особливості проведення екскурсій 3 природознавства у початковій школі. Початкова школа, 6, с. 23-26.

Гільберг, Т. та Тарнавська, С. (2019) Особливості та роль екскурсій у пізнанні навколишнього світу. Початкова школа, 11, с. 31-38.

Тарасун,В.В. (2011) Логодидактика. Київ: Видавничий дім «Слово», 392 с.

Рібцун, Ю.В. (2020) Учні початкових класів із тяжкими порушеннями мовлення: навчання та розвиток. Львів: Світ, 264 с.

Шибецька, В. та Кравець, Н. (2015) Екскурсія як засіб збагачення уявлень про природу в молодших школярів 3 порушенням інтелекту. «Молодий вчений» Науковий журнал, 2(17), с. 151-154.

\section{REFERENCES}

Sukhomlynskyi, V. (1977). Vybrani tvory v 5 t. T. 3: Sertse viddaiu ditiam; Narodzhennia hromadianyna; Lysty do syna. [Selected works in 5 volumes. Volume 3: I give my heart to children; Birth of a citizen; Letters to the son.]. Kyiv: "Radianska shkola", 668 s. [in Ukrainian].

Derzhavnyi standart pochatkovoi osvity [State standard of primary education]. (2018).

URL:

https://www.kmu.gov.ua/storage/app/uploads/public/5a8/de2/5e1/5a8de25e1504c87758 3228.doc [Data zvernennia 28.08.2021]. [in Ukrainian].

Hilberh,T., Tarnavska, S. ta Pavych, N (2019). Nova ukrainska shkola: metodyka navchannia intehrovanoho kursu «Ia doslidzhuiu svit» u 1-2 klasakh zakladiv serednoi osvity na zasadakh kompetentnisnoho pidkhodu [New Ukrainian school: methods of teaching an integrated course "I explore the world" in grades 1-2 of secondary schools on the basis of a competency-based approach] Kyiv: "Heneza", 256 s. [in Ukrainian].

Baibara, T. (1998). Metodyka navchannia pryrodoznavstva v pochatkovykh klasakh. [Methods of teaching science in primary school]. Kyiv: Veselka, $338 \mathrm{~s}$. [in Ukrainian].

Vasiutina, T. (2017). Metodychni osoblyvosti provedennia ekskursii $z$ pryrodoznavstva u pochatkovii shkoli [Methodical features of conducting excursions in natural sciences in primary school]. Pochatkova shkola, 6, s. 23-26. [in Ukrainian].

Hilberh, T. ta Tarnavska, S. (2019). Osoblyvosti ta rol ekskursii u piznanni navkolyshnoho svitu [Features and role of excursions in the knowledge of the surrounding world]. Pochatkova shkola, 11, s. 31-38. [in Ukrainian].

Tarasun,V.V. (2011). Lohodydaktyka [Logodidacty]. Kyiv: Vydavnychyi dim «Slovo», 392 s. [in Ukrainian].

Ribtsun, Yu.V. (2020). Uchni pochatkovykh klasiv iz tiazhkymy porushenniamymovlennia: navchannia ta rozvytok [Primary school students with severe speech disorders: learning and development]. Lviv: Svit, 264 s. [in Ukrainian].

Shybetska, V. ta Kravets, N. (2015). Ekskursiia yak zasib zbahachennia uiavlen pro pryrodu $\mathrm{v}$ molodshykh shkoliariv z porushenniam intelektu [Excursion as a means of enriching ideas about nature in junior high school students with intellectual disabilities]. "Molodyi vchenyi". Naukovyi zhurnal, 2(17), s. 151-154. [in Ukrainian]. 


\title{
PREPARATION AND CONDUCTING EDUCATIONAL EXCURSIONS IN NATURE WITH YOUNG SCHOOLCHILDREN WITH SPEECH DISORDERS
}

\author{
Nataliia Horopakha \\ Candidate of Pedagogical Sciences, Associate Professor, \\ Associate Professor at prof. T.I. Ponimanska \\ Preschool Pedagogy and Psychology \\ and special education, \\ Rivne State University of Humanities, \\ Rivne, Ukraine \\ ORCID: 0000-0002-5406-1963 \\ e-mail: nataliia.horohakha@rshu.edu.ua
}

\begin{abstract}
The article considers the use of nature excursions as a form of studying science with younger students with speech disorders. Particular attention is paid to the importance of excursions in the formation of defined by the State standard of primary education of natural and environmental competencies of primary school children. The main value of the tour is that it allows students to get closer to nature, show them the integrity, unity and diversity of the natural world, the presence of certain connections and patterns, which are more clearly traced on the tour. Excursion is also a recognized means of increasing the interest of younger students in learning about nature. The author considers the classification of excursions and their structure. The role of excursions in the correctional component of the study of natural sciences in a special primary school for children with severe speech disorders is highlighted. The availability of additional opportunities during the tour to stimulate students' speech development makes this form of science study so important in a special primary school or inclusive classroom where students with speech disorders study. The author argues that the effectiveness of the tour largely depends on how well thought out by the teacher its structure, how it provides for the solution of certain didactic and corrective goals. It is proposed to include in the structure of the excursion preparatory and post-excursion work with students, as well as a pedestrian crossing from the school to the place of the excursion and back. Examples of methodical methods of teacher's work at the stage of preparation of junior schoolchildren with severe speech disorders for excursion, during pedestrian crossing and in post-excursion work, recommendations on organization of observations are given. It is also emphasized that the preparation and conduct of excursions with students of special primary schools for children with speech disorders requires the teacher to take into account the difficulties they have in learning in general and in learning about the natural environment in particular.
\end{abstract}

Keywords: excursion, junior school children, natural sciences, speech disorders, excursion preparation, observations, post-excursion work.

Стаття надійшла до редакиії 07.10.2021 p. 